
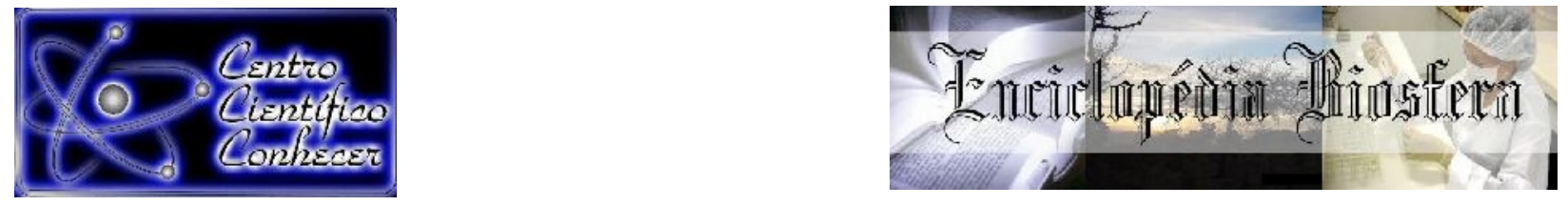

\title{
ANTIOXIDANT ACTIVITY AND TOTAL PHENOL, FLAVONOID AND TANNIN CONTENTS OF Croton floribundus AND Croton urucurana
}

\author{
Ana Francisca Gomes da Silva ${ }^{1}$, Bruno Henrique Feitosa ${ }^{2}$, Vânia Tomazelli \\ Lima $^{3}$, Valéria Flávia Batista da Silva ${ }^{4}$ \\ ${ }^{1}$ Professora Doutora dos cursos de Ciências Biológicas e Tecnologia em Gestão \\ Ambiental da Universidade Estadual de Mato Grosso do Sul (UEMS), Mundo \\ Novo-MS, Brasil. (anafranciscagomesdasilva@gmail.com) \\ ${ }^{2}$ Graduando em Ciências Biológicas, Universidade Estadual de Mato Grosso do \\ Sul (UEMS), Mundo Novo-MS, Brasil. \\ ${ }^{3}$ Doutoranda em Biologia Vegetal/Universidade Estadual Paulista (UNESP), Rio \\ Claro-SP, Brasil. \\ ${ }^{4}$ Professora Doutora do curso de Ciências Biológicas da Universidade Estadual de \\ Mato Grosso do Sul (UEMS), Mundo Novo-MS, Brasil
}

Recebido em: 04/10/2019 - Aprovado em: 30/11/2019 - Publicado em: 15/12/2019 DOI: 10.18677/EnciBio_2019B2

\begin{abstract}
The present study aimed to carry out the phytochemical screening, evaluate the antioxidant activity, and determine the total phenol, flavonoid and tannin contents of the ethanolic extracts from leaves of Croton floribundus and Croton urucurana. The preliminary analysis of the chemical composition was performed by in vitro tests, with specific reagents for different classes of secondary metabolites. The antioxidant activity was evaluated by the 2,2-diphenyl-1-picrylhydrazyl free radical (DPPH) scavenging method and the quantification of total phenols, flavonoids and tannin by spectrophotometry in the visible region. The phytochemical results indicated the presence of triterpenes and/or steroids, flavonoids and tannins in both species and purines only in C. floribundus. C. floribundus extract was the most active for the antioxidant activity $\left(\mathrm{IC}_{50}=105.79 \pm 2.40 \mathrm{~g} / \mathrm{mL}\right)$ and also presented the highest content of total phenols $(91.41 \pm 1.13 \mathrm{mg} \mathrm{GAE} / \mathrm{g})$ and total tannins $(60.33 \pm 1.22 \mathrm{mg} \mathrm{TAE} / \mathrm{g})$. C. urucarana extract had a IC 50 of $120.34 \pm 3.42$ $\mathrm{g} / \mathrm{mL}$ and higher total flavonoid content $(77.74 \pm 2.06 \mathrm{mg} \mathrm{QE} / \mathrm{g})$. The results indicate that $C$. floribundus and $C$. urucurana have moderate antioxidant potential, which is related to the presence of phenolic compounds such as flavonoids and tannins.
\end{abstract}

KEYWORDS: Euphorbiaceae, phenolic compounds, phytochemistry. 


\section{ATIVIDADE ANTIOXIDANTE E TEORES DE FENÓIS, FLAVONOIDES E TANINOS TOTAIS DE Croton urucurana E Croton floribundus}

\section{RESUMO}

O presente estudo teve como objetivo realizar a triagem fitoquímica, avaliar a atividade antioxidante, bem como determinar o teor de fenóis, flavonoides e taninos totais dos extratos etanólicos e das folhas de Croton urucurana e Croton floribundus. A análise preliminar da composição química foi realizada por testes in vitro, com reagentes específicos para diferentes classes de metabólitos secundários. A atividade antioxidante foi avaliada pelo método de sequestro do radical livre 2,2-difenil-1-picrilidrazila (DPPH) e a quantificação de fenóis, flavonoides e taninos totais por espectrofotometria na região do visível. Os testes fitoquímicos indicaram a presença de triterpenoides e/ou esteroides, flavonoides e taninos em ambas as espécies e purinas apenas em $C$. floribundus. $O$ extrato de C. floribundus foi o mais ativo em relação à atividade antioxidante $\left(\mathrm{Cl}_{50}=105,79 \pm\right.$ $2,40 \mathrm{~g} / \mathrm{mL})$ e também o que apresentou o maior teor de fenóis totais $(91,41 \pm$ $1,13 \mathrm{mg}$ EAG/g) e taninos totais $(60,33 \pm 1,22 \mathrm{mg} \mathrm{EAT} / \mathrm{g})$. O extrato de $C$. urucarana registrou $\mathrm{Cl}_{50}$ de $120,34 \pm 3,42 \mathrm{~g} / \mathrm{mL}$ e maior teor de flavonoides totais $(77,74 \pm 2,06 \mathrm{mg} \mathrm{EQ} / \mathrm{g})$. Os resultados indicam que $C$. floribundus e $C$. urucurana apresentam moderado potencial antioxidante relacionado a presença de compostos fenólicos como flavonoides e taninos.

PALAVRAS-CHAVE: Compostos fenólicos, Euphorbiaceae, fitoquímica.

\section{INTRODUCTION}

Croton $\mathrm{L}$. is a genus belonging to the family Euphorbiaceae containing about 1,300 species distributed predominantly in the American continent. In South America, Brazil is the most representative country of this genus, with about 350 species distributed in different regions (VAN EE et al., 2011). This genus has a significant number of species used in folk medicine performing different functions against various diseases (COY BARRERA et al., 2016; TRINDADE; LAMEIRA, 2014).

Chemically, Croton stands out for the production of diterpenes (MACIEL et al., 2006; PIZZOLATTI et al., 2013). Other secondary metabolites include triterpenes, flavonoids, alkaloids and phenylpropanoids (CANELO et al., 2017; SANTOS et al., 2015; RAVANELLI et al., 2016; ALVES et al.; 2017). A broad biological action is attributed to these metabolites and to extracts and/or fractions obtained from species of the genus, such as antioxidant, cytotoxic, mutagenic and antimicrobial activities (AQUINO et al., 2017; SANTOS et al., 2015; ALMEIDA et al., 2019).

Croton floribundus Spreng, popularly known as capixingui, occurs in the Atlantic Forest, in anthropic area, riparian vegetation and seasonal semideciduous forest (CORDEIRO et al., 2015a). This species is used in reforestation of degraded areas, in agroforestry and silviagricultural systems and also in traditional medicine as anti-inflammatory, healing, tonic, in the treatment of syphilis, hemorrhoids and ulcers (NICODEMO et al., 2016; BARTH et al., 2018). Chemically there are few studies in the literature on leaves and bark of $C$. floribundus. Regarding biological potential, cytotoxic, antioxidant, antimicrobial, 
molluscicidal, and cercaricidal activities are reported (UCHÔA et al., 2013; BARTH et al., 2018; MEDINA et al., 2009).

Croton urucurana Baillon ccurs in Seasonal Semideciduous Forest, Ombrophilous Forest and mainly Riparian or Gallery (CORDEIRO et al., 2015b). It is used in reforestation for landscape recovery and shading later species (MARTINS et al., 2015). Popularly known as sangra d'água, it is used as antiinflammatory, anti-hemorrhagic, healing, in the fight against prostate cancer, diabetes and kidney disease (ANTONIAZZI et al., 2016). Some studies report the chemical composition and biological actions for latex, essential oil and different parts of the plant, highlighting cytotoxic, antimicrobial and antinociceptive activities (CANDIDO-BACANI et al., 2015; SIMIONATTO et al., 2007; SIMIONATTO et al., 2009; VIEIRA et al., 2017; CORDEIRO et al., 2016).

Considering the biological potential of species of the genus Croton, this study aimed to make the phytochemical screening and to evaluate the antioxidant activity, as well as to determine the total phenol, flavonoid and tannin contents of the ethanolic leaf extracts of $C$. floribundus and $C$. urucurana occurring in the State of Mato Grosso do Sul.

\section{Collection and identification of plant material \\ MATERIAL AND METHODS}

The plant material (leaves) was obtained from matrices distributed in remnant areas of Cerrado in September 2018, in the municipality of Dourados, State of Mato Grosso do Sul. The exsiccates were deposited in the DDMS herbarium of the Federal University of Grande Dourados (UFGD), with the record numbers 2699 and 5536 respectively.

\section{Preparation of extracts}

The leaves were air-dried, ground in a knife mill (Wiley) and cold extracted with ethanol. Each extract was filtered and concentrated under reduced pressure. Thus, $21.67 \mathrm{~g}$ crude extract of $C$. floribundus and $23.29 \mathrm{~g}$ crude extract of $C$. urucurana were obtained.

\section{Screening fitoquímico}

Conventional tests in phytochemical analysis were performed with the samples in order to verify the presence of triterpenes and/or steroids, flavonoids, tannins, purines, alkaloids, sesquiterpene lactones and other lactones, saponins and catechins, especially under coloration and/or characteristic precipitate (SIMÕES et al., 2010).

\section{Antioxidant activity}

The antioxidant capacity of natural substances can be evaluated spectrophotometrically by the ease with which the stable free radical 2,2-diphenyl1-picrylhydrazyl (DPPH) receives a hydrogen atom from a potentially antioxidant substance. In solution this radical has an intense violet color resulting from the unpaired electron and absorbs at $517 \mathrm{~nm}$. A decrease in this wavelength occurs by radical stabilization by receiving a radical hydrogen from the antioxidant species, which is indicated by the loss of color (OLIVEIRA et al., 2015).

The assay was done according to the methodology described in the literature (SOUSA et al., 2007) with modifications. Sample solutions of different 
concentrations were prepared (250 to $25 \mathrm{~g} / \mathrm{mL}$ ) and the absorbance measurements of the reaction mixtures $(1 \mathrm{~mL}$ of the sample solution and $2.5 \mathrm{~mL}$ of $0.1 \mathrm{mM}$ DPPH methanolic solution) were recorded at the end of 30 and 60 minutes in a UV/vis Tecnal spectrophotometer at $515 \mathrm{~nm}$, having quercetin as a positive control. From the absorbance values at 60 minutes, the percentages of oxidation inhibition of the radical were calculated according to Equation:

$$
\% \text { Reduction }\left(\mathrm{DPPH} \mathrm{H}_{\text {consumed }}\right)=\left[\mathrm{A}_{\text {control }}-\mathrm{A}_{\text {sample }} / \mathrm{A}_{\text {control }}\right] \times 100
$$

Where, $A_{\text {control }}$ is the initial absorbance of DPPH at the concentration of 0.1 $\mathrm{mM}$ and $\mathrm{A}_{\text {sample }}$ corresponds to the absorbance of DPPH in the medium, after the reaction with the sample. The inhibitory concentration $\left(\mathrm{IC}_{50}\right)$ was obtained through interpolation of linear regression analysis.

\section{Total phenols}

The content of total phenolic compounds was determined by the FolinCiocalteau spectrophotometric method with modifications (SOUSA et al., 2007). To a $1.0 \mathrm{~mL}$ aliquot of sample methanolic solution $(1 \mathrm{mg} / \mathrm{mL})$ was added $5 \mathrm{~mL}$ distilled water and Folin- Ciocalteau reagent $(0.2 \mathrm{~mL})$. The solution was stirred for 1 minute and $0.6 \mathrm{~mL} 15 \% \mathrm{Na}_{2} \mathrm{CO}_{3}$ was added. The volume was made up to $10 \mathrm{~mL}$ with distilled water. After $1 \mathrm{~h}$ and 30 minutes, the absorbance of the samples was red at $750 \mathrm{~nm}$ in a UV/vis Tecnal spectrophotometer. Gallic acid was used as standard for the construction of the calibration curve $(15.625$ to $250 \mathrm{~g} / \mathrm{mL}$; y = $0.009 x+0.0763 ; R 2=0.997)$. The analyses were performed in triplicate, and the results were expressed as milligram of gallic acid equivalent per gram sample (mg $\mathrm{GAE} / \mathrm{g})$.

\section{Total flavonoids}

The determination of the total flavonoid content was performed by the aluminum chloride colorimetric method (PARTHASARATHI; PARK, 2015). $1 \mathrm{~mL}$ of the sample methanolic solution $(1 \mathrm{mg} / \mathrm{mL}$ ) was mixed with $0.2 \mathrm{~mL} 2.5 \%$ aluminum chloride $\left(\mathrm{AlCl}_{3}\right)$ in $\mathrm{MeOH}$ and the volume completed to $10 \mathrm{~mL}$. After standing for 30 minutes, the absorbance was read using a UV/vis Tecnal spectrophotometer at $425 \mathrm{~nm}$. The total flavonoid content was determined using a quercetin calibration curve at concentrations of 6.25 to $200 \mu \mathrm{g} / \mathrm{mL}$ and the equation of the curve obtained was $y=0.0084 x+0.033 ; R 2=0.998$. The analyses were performed in triplicate, and the results expressed in milligram of quercetin equivalent per gram sample (mg QE/g).

\section{Total tannins}

The total tannin dosage was determined by the Folin-Denis spectrophotometric method (PANSERA et al., 2003). To $1.0 \mathrm{~mL}$ of sample solution $(1 \mathrm{mg} / \mathrm{mL})$ Folin-Denis reagent $(1 \mathrm{~mL})$ was added, then the solution was stirred for 1 minute and $0.5 \mathrm{~mL}$ of $25 \% \mathrm{Na}_{2} \mathrm{CO}_{3}$ was added. The volume was made up to 10 $\mathrm{mL}$ with distilled water. After 30 minutes, the absorbance of the samples was measured at $725 \mathrm{~nm}$ in a UV/vis Tecnal spectrophotometer. The total tannin content was determined using a calibration curve constructed with tannic acid standards (7.8125 a $500 \mathrm{~g} / \mathrm{mL})$. The equation of the curve was $\mathrm{y}=0.0042 \mathrm{x}+$ 
$0.0923 ; \mathrm{R} 2=0.996$. The analyses were performed in triplicate, the results expressed as mg of tannic acid equivalent per gram of sample (mg TAE/g).

\section{Statistical analysis}

The results were expressed as mean \pm standard deviation $(n=3)$ for each extract. The statistical treatment of the data was done by analysis of variance (ANOVA) using the computer program Sisvar 5.6. The value $p<0.05$ was considered statistically significant.

\section{Screening fitoquímico}

\section{RESULTS AND DISCUSSION}

The leaves of $C$. floribundus and $C$. urucurana were chemically analyzed to determine the profile of their main groups of secondary metabolites. Thus, the phytochemical screening made it possible to detect the presence of groups of bioactive secondary metabolites such as triterpenes and/or steroids, flavonoids and tannins in both species and purines only in $C$. floribundus. Phytochemical tests indicated the absence of alkaloids, sesquiterpenlactones and other lactones, saponins and catechins.

Previous study reports that phytochemical screening of $C$. urucurana revealed the presence of flavonoids and tannins in leaf extracts, but no triterpenes and/or steroids were identified (SILVA et al., 2017). In another study, steroids were obtained from stem bark extracts (PERES et al., 1997). For C. floribundus, different diterpene compounds were obtained (UCHÔA et al., 2013; MEDINA et al., 2009). These variations of secondary metabolites for the same species can be justified by several environmental factors such as seasonality, circadian rhythm, development stage, temperature, water availability, UV radiation, soil nutrients, altitude, atmospheric composition, among others (GOBBO-NETO; LOPES, 2007).

\section{Antioxidant activity}

The formation of free radicals is a continuous and physiological action, which plays essential biological functions in the organism (RAHAL et al., 2014). However, its excess may cause oxidative damage to various biomolecules such as proteins and deoxyribonucleic acid (SOUSA et al., 2007). This process contributes to the development of degenerative diseases associated with aging, such as cancer, cardiovascular diseases and brain dysfunctions (OLIVEIRA et al., 2015). Several studies have shown that plant extracts can exert antioxidant action and are indicated to attenuate or prevent the effects of oxidative stress (VIEIRA et al., 2015).

The DPPH free radical scavenging assay is a frequently used chemical method for the investigation of the antioxidant potential of plant extracts. Thus, the results were expressed as the ability to reduce the DPPH radical in percentage (Figure 1) and the $\mathrm{IC}_{50}$ value (Table 1 ), which is a parameter indicative of the inhibitory concentration required to decrease the DPPH free radical by $50 \%$. The lower the value of $\mathrm{IC}_{50}$, the higher the antioxidant activity (OLIVEIRA et al., 2015).

Regarding the ability to scavenge the DPPH radical (\% DPPH reduction) of the analyzed samples, both $C$. floribundus and $C$. urucurana samples showed differences in the tested concentrations ( $p \quad 0.05$ ). Only $C$. floribundus extract did not differ in radical reduction at concentrations of 50 and $25 \mathrm{~g} / \mathrm{mL}$ (Figure 1). At higher concentrations (250 and $200 \mathrm{~g} / \mathrm{mL}$ ), the extracts reduced the radical by 
more than $60 \%$. There was significant difference between $C$. floribundus and $C$. urucurana samples only for the $25 \mathrm{~g} / \mathrm{mL}$ concentration.

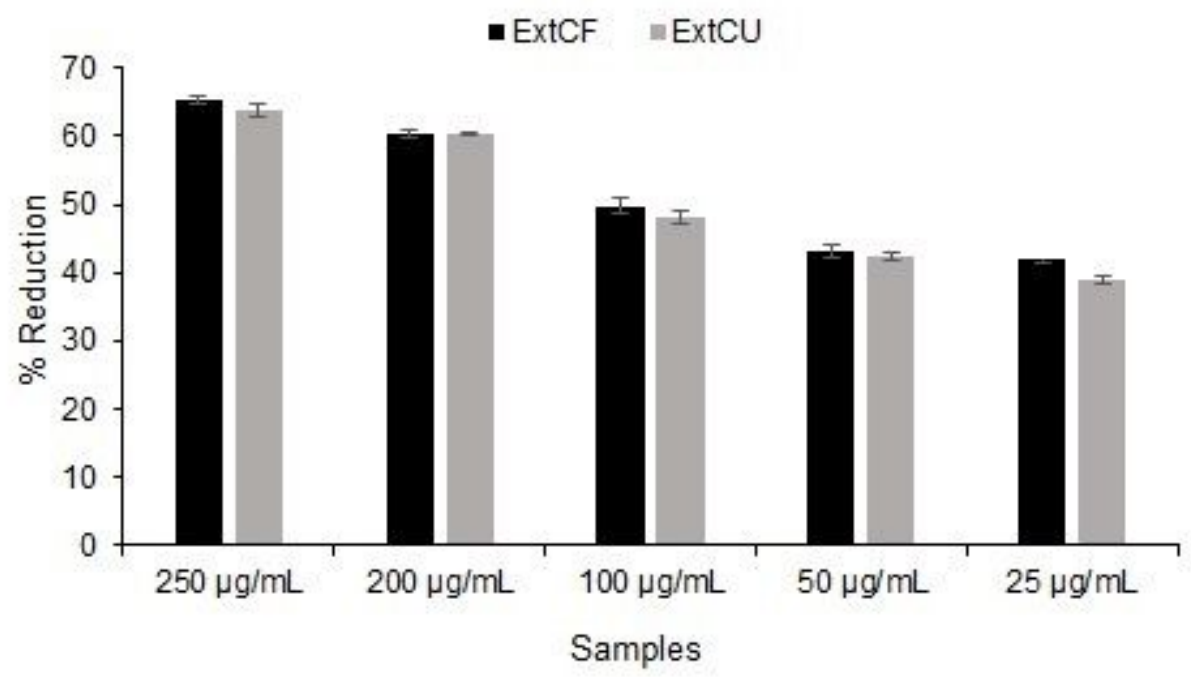

FIGURA 1- Percentage of DPPH reduction of crude ethanolic extracts from leaves of $C$. floribundus (ExtCF) and $C$. urucurana (ExtCU).

Based on the $\mathrm{IC}_{50}$ values of the extracts (Table 1), the highest effectiveness in antioxidant capacity was for the crude ethanolic extract of $C$. floribundus leaves $\left(\mathrm{IC}_{50}=105.79 \pm 2.40 \mathrm{~g} / \mathrm{mL}\right)$. In turn, the extract from $C$. urucurana had $\mathrm{IC}_{50}$ of $120.34 \pm 3.42 \mathrm{~g} / \mathrm{mL}$. Samples showed less antioxidant activity than the quercetin standard $\left(\mathrm{IC}_{50}=4.07 \pm 1.43\right)$.

TABLE 1- Total phenol, flavonoid, tannin contents and $I_{50}$ of crude extracts from leaves of $C$. floribundus and $C$. urucurana

\begin{tabular}{ccccc}
\hline Samples & $\begin{array}{c}\text { Total phenols } \\
(\mathrm{mg} \mathrm{GAE} / \mathrm{g})\end{array}$ & $\begin{array}{c}\text { Total flavonoids } \\
(\mathrm{mg} \mathrm{QE} / \mathrm{g})\end{array}$ & $\begin{array}{c}\text { Total tannins } \\
(\mathrm{mg} \mathrm{TAE} / \mathrm{g})\end{array}$ & $\begin{array}{c}\mathrm{IC}_{50} \\
(\mathrm{~g} / \mathrm{mL})\end{array}$ \\
\hline ExtCF & $91.41 \pm 1.13 \mathrm{a}$ & $54.32 \pm 2.99 \mathrm{~b}$ & $60.33 \pm 1.22 \mathrm{a}$ & $105.79 \pm 2.40 \mathrm{~b}$ \\
ExtCU & $79.97 \pm 0.67 \mathrm{~b}$ & $77.74 \pm 2.06 \mathrm{a}$ & $52.55 \pm 2.81 \mathrm{~b}$ & $120.34 \pm 3.42 \mathrm{a}$ \\
Quercetin & - & - & - & $4.07 \pm 1.43$
\end{tabular}

Values expressed as mean \pm standard deviation $(n=3)$. Means followed by different letters in the same column are significantly different after ANOVA ( $p$ 0.05). Crude extracts from leaves of C. floribundus (ExtCF) and C. urucurana (ExtCU).

Barth et al. (2018) report for $C$. floribundus leaf and bark extracts $I_{50}$ values of $61.2 \mu \mathrm{g} / \mathrm{ml}$ and $62.2 \mu \mathrm{g} / \mathrm{ml}$, respectively. However, antioxidant action more effective than that reported in this work. For $C$. urucurana the essential oil of stem bark was investigated and exhibited $I_{50}$ of $3.21 \mathrm{mg} / \mathrm{mL}$ (SIMIONATTO et al., 2007), in another study leaf extracts showed high antioxidant activity (SILVA et al., 2017). 
Other species of the genus were also evaluated for antioxidant potential. Ndhlala et al. (2013) obtained for crude leaf extracts of Croton gratissimus and Croton zambesicus values of $\mathrm{IC}_{50}=58.47 \pm 5.06 \mu \mathrm{g} / \mathrm{mL}$ and $1018.15 \pm 55.85$ $\mu \mathrm{g} / \mathrm{mL}$, respectively. Comparing with the species evaluated in this study, $C$. zambescius was much less effective, as well as the methanolic extract of Croton bonplandianum which recorded $\mathrm{IC}_{50}$ values $=396.205 \pm 4.6 \mu \mathrm{g} / \mathrm{mL}$ (QAISAR et al. 2013). However, Costa et al. (2017) obtained for the ethanol extract of the stem high antioxidant potential ( $\mathrm{IC}_{50}$ of $\left.9.75 \pm 0.058 \mu \mathrm{g} / \mathrm{mL}\right)$.

The results obtained in the determination of total phenols, flavonoids and tannins are listed in table 1. Comparing the species, C. floribundus extract showed the highest total phenol and total tannin contents $(91.41 \pm 1.31 \mathrm{mg} \mathrm{GAE} / \mathrm{g}$ and $60.33 \pm 1.22 \mathrm{mg} \mathrm{TAE} / \mathrm{g}$, respectively). While $C$. urucurana presented a higher total flavonoid content $(77.74 \pm 2.06 \mathrm{mg} \mathrm{QE} / \mathrm{g})$.

For the ethanolic leaf extract of Croton argyrophylloides, Silva et al. (2016) recorded total phenol and flavonoid contents of $86.4 \pm 7.7 \mathrm{mg} \mathrm{GAE} / \mathrm{g}$ and $37.4 \pm$ $1.1 \mathrm{mg} \mathrm{RE} / \mathrm{g}$, respectively. Such results are inferior to those found in this study. However, Costa et al. (2017) evaluated the crude ethanol extract of Croton argyrophyllus, and reported higher total phenol and flavonoid contents with values of $269.72 \pm 6.25 \mathrm{mg} \mathrm{GAE} / \mathrm{g}$ and $98.43 \pm 1.39 \mathrm{mg} \mathrm{QE} / \mathrm{g}$, respectively. In the same way, Morais et al. (2013) analyzed various herbal extracts and found phenolic compound content at $120.27 \mathrm{mg} \mathrm{GAE} / \mathrm{g}$ extract in Croton zenhtneri ethanolic extract.

The antioxidant potential of plant extracts is usually related to the presence of phenolic compounds such as simple phenols, flavonoids, tannins and coumarins. These compounds are included in the category of free radical scavengers, being very efficient in the prevention of the oxidative process (SOUSA et al., 2007; SANTOS; RODRIGUES, 2017).

In the case of the tested species, this approach can be applied, because C. floribundus extract, the most active in relation to antioxidant activity $\left(\mathrm{IC}_{50}=\right.$ $105.79 \pm 2.40 \mathrm{~g} / \mathrm{mL}$ ) also presented the highest content of phenolic compounds $(91.41 \pm 1.13 \mathrm{mg} \mathrm{EAG/g})$. Considering these results, it is possible that the main phenolic constituents are flavonoids and tannins, compounds recognized as antioxidants, evidenced in the phytochemical screening and quantified in this study.

\section{CONCLUSIONS}

The results obtained in this study indicate that the leaf extracts of $C$. floribundus and $C$. urucurana contain bioactive substances belonging to the groups of triterpenes and/or steroids, flavonoids, tannins and purines, with moderate antioxidant potential related to the presence of phenolic compounds such as flavonoids and tannins, evaluated in this study.

\section{ACKNOWLEDGEMENT}

The authors are grateful to the Fundação de Apoio ao Desenvolvimento do Ensino, Ciência e Tecnologia do Estado de Mato Grosso do Sul (FUNDECT) for financial support (process 59/300.308/2016). 


\section{REFERENCES}

ALMEIDA, F. K. V.; NOVAIS, V. P.; SALVI, J. O.; MARSON, R. F. Avaliação tóxica, citotóxica e mutagênica/genotóxica de um extrato comercial de sangue do dragão (Croton lechleri). Revista Fitos, v. 13, n. 1, p. 29-37, 2019. Available in: https://doi.org/10.17648/2446-4775.2019.605>. doi. 10.17648/24464775.2019 .605

ALVES, I. A.; SANTOS, S. M.; MENDES, R. F.; SILVA, J. E.; RODRIGUES, M. D. et al. Chemical composition, antioxidant and topical anti-inflammatory activities of Croton cordiifolius Baill. (Euphorbiaceae). Journal of medicinal plant research, v. $11, \quad$ n. 2 , p. 22-33, 2017. Available in: https://doi.org/10.5897/JMPR2015.6294>. doi. 10.5897/JMPR2015.6294

ANTONIAZZI, C. A.; BOTINI, N.; ASCARI, K.; CHAVES, C. F.; AÑEZ, R. B. Estudo Etnobotânico de Croton urucurana Baill (Euphorbiaceae) na comunidade Salobra Grande, Porto Estrela-MT. Biodiversidade, v. 15, n. 2, p. 40-52, 2016. Available in: https://pdfs.semanticscholar.org/cd54/bde596d106ee553c9312126b70e59c4ada 03.pdf?>

AQUINO, V. V. F.; COSTA, J. G. M.; ANGÉLICO, E. C.; MEDEIROS, R. S.; ARAÚJJ, M. F. et al. Metabólitos Secundários e ação antioxidante de Croton heliotropiifolius e Croton blanchetianus. Acta Brasiliensis, v. 1, n. 3, p. 7-10, 2017. Available in: https://doi.org/10.22571/Actabra13201730>. doi. 10.22571/Actabra13201730

BARTH, E. F.; PINTO, L. S.; DILELI, P.; BIAVATTI, D. C.; SILVA, Y. L. et al. Biological screening of extracts from leaf and stem bark of Croton floribundus Spreng. (Euphorbiaceae). Brazilian Journal of Biology, v. 78, n. 4, p. 601-608, 2018. Available in: http://dx.doi.org/10.1590/1519-6984.166522>. doi. $10.1590 / 1519-6984.166522$

CANDIDO-BACANI, P. M.; FIGUEIREDO, P. O.; MATOS, M. F. C.; GARCEZ, F. R.; GARCEZ, W. S. Cytotoxic Orbitide from the Latex of Croton urucurana. Journal of Natural Products, v. 78, n. 11, p. 2754-2760, 2015. Disponível em: https://doi.org/10.1021/acs.jnatprod.5b00724>. 10.1021/acs.jnatprod.5b00724

CANELO, L. I. N.; MAFUCA, I.; MATA, R. S.; MENDONÇA, D. I. Composição química de uma população de Croton gratissimus Burch (Euphorbiaceae). Química Nova, v. 40, n. 9, p. 1035-1038, 2017. Available in: http://dx.doi.org/10.21577/0100-4042.20170101>. doi. 10.21577/01004042.20170101

CORDEIRO, I.; SECCO, R.; CARNEIRO-TORRES, D.S.; LIMA, L.R.; CARUZO, M.B.R. et al. Croton in Lista de Espécies da Flora do Brasil. Jardim Botânico do Rio de Janeiro. 2015a. Available in: $<$ http://floradobrasil.jbrj.gov.br/jabot/floradobrasil/FB17512>. 
CORDEIRO, I.; SECCO, R.; CARNEIRO-TORRES, D. S.; LIMA, L. R.; CARUZO, M. B. R. et al. Croton in Lista de Espécies da Flora do Brasil. Jardim Botânico do Rio de Janeiro. 2015b. Available in: $<$ http://floradobrasil.jbri.gov.br/jabot/floradobrasil/FB17546>

CORDEIRO, K. W.; FELIPE, J. L.; MALANGE, K. F.; PRADO, P. R.; FIGUEIREDO, P. O. et al. Anti-inflammatory and antinociceptive activities of Croton urucurana Baillon bark. Journal of Ethnopharmacology, v. 183, n. 13, p. 128-135, 2016. Available in: https://doi.org/10.1016/j.jep.2016.02.051>. doi. 10.1016/j.jep.2016.02.051

COSTA, M. A. R.; SANTOS, R. R. C.; GUALBERTO, S. A.; SILVA, S. L. C. Fenólicos totais, flavonoides totais e atividade antioxidante de extratos de Croton argyrophyllus Kunth (Euphorbiaceae). Enciclopédia biosfera, v. 14, n. 25, p. 687701, 2017. Available in: https://doi.org/10.18677/EnciBio_2017A53>. doi. 10.18677/EnciBio_2017A53

COY BARRERA, C. A.; GÓMEZ, D. C.; CASTIBLANCO, F. A. Importancia medicinal del género Croton (euphorbiaceae). Revista Cubana de Plantas Medicinales, v. 21, n. 2, p. 234-247, 2016. Available in: https://www.medigraphic.com/pdfs/revcubplamed/cpm-2016/cpm162k.pdf>

GOBBO-NETO, L.; LOPES, N. P. Plantas medicinais: fatores de influência no conteúdo de metabólitos secundários. Química Nova, v. 30, n. 2, p. 374-381, 2007. Available in: http://dx.doi.org/10.1590/S0100-40422007000200026. doi. 10.1590/S0100-40422007000200026

MACIEL, M. A. M.; CORTEZ, J. K. P. C.; GOMES, F. E. S. O Gênero Croton e aspectos relevantes de diterpenos clerodanos. Revista Fitos, v. 2, n. 3, p. 54-73, 2006. Available in: https://www.arca.fiocruz.br/bitstream/icict/18405/2/4.pdf>

MARTINS, A. C. F.; SCHIAVINI, I.; ARAÚJO, G. M.; LOPES, S. F. Capacidade adaptativa de espécies do cerrado utilizadas em áreas de recuperação ambiental ${ }^{1}$. Revista Árvore, v. 39, n. 3, p. 543-550, 2015. Available in: http://dx.doi.org/10.1590/0100-67622015000300015>

MEDINA, J. M.; PEIXOTO, J. L. B.; SILVA, A. A.; HARAGUCHI, S. K.; FALAVIGNA, D. L. M. et al. Evaluation of the molluscicidal and Schistosoma mansoni cercariae activity of Croton floribundus extracts and kaurenoic acid. Revista Brasileira de Farmacognosia, v. 19, n. 1b, p. 207-211, 2009. Available in: http://dx.doi.org/10.1590/S0102-695X2009000200005>. doi. 10.1590/S0102$695 \times 2009000200005$

MORAIS, S. M.; LIMA, K. S. B.; SIQUEIRA, S. M. C.; CAVALCANTI, E. S. B.; SOUZA, M. S. T. et al. Correlação entre as atividades antiradical, antiacetilcolinesterase e teor de fenóis totais de extratos de plantas medicinais de farmácias vivas. Revista Brasileira de Plantas Medicinais, v. 15, n. 4, p. 575582, 2013. Available in: http://dx.doi.org/10.1590/S1516-05722013000400014>. doi. $10.1590 / \mathrm{S} 1516-05722013000400014$ 
NDHLALA, A. R.; ADEROGBA, M. A.; NEUBE, B.; STADEN, J. V. Anti-oxidative and cholinesterase inhibitory effects of leaf extracts and their isolated compounds from two closely related Croton species. Molecules, v. 18, n. 2, p. 1916-1932, 2013. Available in: <http://dx.doi.org/10.3390/molecules18021916>. doi. 10.3390/molecules18021916

NICODEMO, M. L. F.; MULLER, M. D.; CARPANEZZI, A. A.; PORFÍRIO-DASILVA, V. Allometric models for estimating aboveground biomass and biomass allocation of capixingui trees (Croton floribundus spreng.) in an agrisilvicultural system. Revista Árvore, v. 40, n. 2, p. 279-288, 2016. Available in: http://dx.doi.org/10.1590/0100-67622016000200010>. doi. 10.1590/010067622016000200010

OLIVEIRA, G. L. S. Determinação da capacidade antioxidante de produtos naturais in vitro pelo método do DPPH•: estudo de revisão. Revista Brasileira de Plantas Medicinais, v. $17, \quad$ n. 1, p. 36-44, 2015. Available in: http://dx.doi.org/10.1590/1983-084X/12_165>. doi. 10.1590/1983-084X/12_165

PANSERA, M. R.; SANTOS, A. C. A.; PACSE, K.; WASUM, R.; ROSSATO, M. et al. Análise de taninos totais emplantas aromáticas e medicinais cultivadas no nordeste do Rio Grande do Sul. Revista Brasileira de Farmacognosia, v. 13, n. 1, p. 17-22, 2003. Available in: http://dx.doi.org/10.1590/S0102695X2003000100002>. doi. 10.1590/S0102-695X2003000100002

PARTHASARATHI, S.; PARK, Y. K. Determination of total phenolics, flavonoid contents and antioxidant activity of different mBHT fractions: A polyherbal medicine. Pakistan Journal of Pharmaceutical Sciences, v. 28, n. 6, p. 21612166, 2015. Available in: https://www.researchgate.net/publication/285458023>

PERES, M. T. L. P.; SIMIONATTO, E.; HESS, S. C.; BONANI, V. F. I.; CANDIDO, A. C. S. et al. Estudos químicos e biológicos de Microgramma vacciniifolia (Langsd. \& Fisch.) Copel (Polypodiaceae). Química Nova, v. 32, n. 4, p. 897-901, 2009. Available in: http://dx.doi.org/10.1590/S0100-40422009000400013>. doi. 10.1590/S0100-40422009000400013

PIZZOLATTI, M. G.; BORTOLUZZI, A. J.; BRIGHENTE, I. M. C.; ZUCHINALLI, A.; CARVALHO, F. K. et al. Clerodane diterpenes from bark of Croton urucurana Baillon. Journal of the Brazilian Chemical Society, v. 24, n. 4, p. 609-614, 2013. Available in: http://dx.doi.org/10.5935/0103-5053.20130075>. doi. 10.5935/0103-5053.20130075

QAISAR, M. N.; CHADARY, B. A.; UZAIR, M.; HUSSAIN, S. N. Evaluation of antioxidant and cytotoxic capacity of Croton bonplandianum. Baill. American Journal of Plant Sciences, v. 4, n. 9, p. 1709-1712, 2013. Available in: <http://dx.doi.org/10.4236/ajps.2013.49208>. doi. 10.4236/ajps.2013.49208 
RAHAL, A.; KUMAR, A.; SINGH, V.; YADAV, B.; TIWARI, R. et al. Oxidative Stress, prooxidants, and antioxidants: The interplay. Hindawi Publishing Corporation BioMed Research International, v. 2014, 19 p. 2014. Available in: http://dx.doi.org/10.1155/2014/761264>. doi. 10.1155/2014/761264

RAVANELLI, N.; SANTOS, K. P.; MOTTA, L. B.; LAGO, J. H. G.; FURLAN, C. M. Alkaloids from Croton echinocarpus Baill.: Anti-HIV potential. South African Journal of Botany, v. 102, p. 153-156, 2016. Available in: https://doi.org/10.1016/j.sajb.2015.06.011>. doi. 10.1016/j.sajb.2015.06.011

SANTOS, K. P.; MOTTA, L. B.; SANTOS, D. Y. A. C.; SALATINO, M. L. F.; SALATINO, A. et al. Antiproliferative activity of flavonoids from Croton sphaerogynus Baill. (Euphorbiaceae). Biomed Research International, v. 2015, 7p, 2015. Available in: http://dx.doi.org/10.1155/2015/212809>. doi. $10.1155 / 2015 / 212809$

SANTOS, A. S.; RODRIGUES, M. M. F. Atividades farmacológicas dos flavonoides: um estudo de revisão. Estação Científica, v. 7, n. 3, p. 29-35, 2017. Available in: https://dx.doi.org/10.18468/estcien.2017v7n3.p29-35>. doi. 10.18468/estcien.2017v7n3.p29-35

SILVA, A. S.; MORAIS, S.; MARTINS, C.; VIEIRA-ARAÚJO, F. Anti-leishmanial and antioxidant potential of the ethanol extract of Croton argyrophylloides Muell. Arg. Revista Eletrônica de Farmácia, v. 13, n. 3, p. 165-171, 2016. Available in: https://doi.org/10.5216/ref.v13i3.35358>. doi. 10.5216/ref.v13i3.35358

SILVA, S. C. S.; ALVES, M. A.; SOUSA, S. A.; NOGUEIRA, J. R. S.; MARTINS, D. H. N. et al. Perfil fitoquímico, susceptibilidade antibacteriana e capacidade antioxidante das folhas de Croton urucurana Baillon (Euphorbiaceae). Infarma, v. 29, n. 3, p. 264-270, 2017. Available in: http://dx.doi.org/10.14450/23189312.v29.e3.a2017.pp264-270>. doi. 10.14450/2318-9312.v29.e3.a2017.pp264270

SIMIONATTO, E.; BONANI, V. F. L.; MOREL, A. F.; POPPI, N. R.; RAPOSO JÚNIOR, J. L. et al. Chemical composition and evaluation af antibacterial and antioxidant activities of the essential oil of Croton urucurana Baillon (Euphorbiaceae) stem bark. Journal of the Brazilian Chemical Society, v. 5, n. 5, p. 879-885, 2007. Available in: http://dx.doi.org/10.1590/S010350532007000500002>. doi. 10.1590/S0103-50532007000500002

SIMIONATTO, E.; BONANI, V. F.; PERES, M. T.; HESS, S. C.; CANDIDO, A. C. et al. Bioactivity and chemical composition of the essential oils of Croton urucurana Baillon (Euphorbiaceae). Journal of essential oil-bearing plants, v. 12, n. 3, p. 250-261, 2009. Available in: https://doi.org/10.1080/0972060X.2009.10643718>. doi. 10.1080/0972060X.2009.10643718 
SIMÕES, C. M. O.; SCHENKEL, E. P.; GOSMANN, G.; MELLO, J. C. P.; MENTZ, L. A. et al. (Orgs). Farmacognosia: da planta ao medicamento. 6. ed. Porto Alegre: UFRGS: Florianópolis: UFSC, 2010. 1104 p.

SOUSA, C. M. M.; SILVA, H. R.; VIEIRA-JR, G. M.; AYRES, M. C. C.; COSTA, C. L. S. et al. Fenóis totais e atividade antioxidante de cinco plantas medicinais. Química Nova, v. $30, \quad$ n. 2, p. 351-355, 2007. Available in: http://dx.doi.org/10.1590/S0100-40422007000200021>. doi. 10.1590/S010040422007000200021

TRINDADE, M. J. S.; LAMEIRA, O. A. Especies de interés de familia Euphorbiaceae en Brasil. Revista Cubana de Plantas Medicinales, v. 19, n. 1, p. 292-309, 2014. Available in: http://scielo.sld.cu/pdf/pla/v19n4/pla02414.pdf>

UCHÔA, P. K. S.; SILVA JR, J. N.; SILVEIRA, E. R.; LIMA, M. A. S. Trachylobane and kaurane diterpenes from Croton floribundus Spreng. Química Nova, v. 36, n. 6, p. 778-782, 2013. Available in: http://dx.doi.org/10.1590/S010040422013000600006>. doi. 10.1590/S0100-40422013000600006

VAN EE, B. W.; RIINA, R.; BERRY, P. E. A revised infrageneric classification and molecular phylogeny of New World Croton (Euphorbiaceae). Taxon, v. 60, n. 3, p. 791-823, 2011. Available in: https://doi.org/10.1002/tax.603013>. doi. $10.1002 / \operatorname{tax} .603013$

VIEIRA, G. T.; OLIVEIRA, T. T.; MONTEIRO, L. P.; KANASHIRO, M. M.; COSTA, M. R. et al. Atividade citotóxica do extrato de Croton urucurana Baill contra linhagens de células leucêmicas humanas U937 e THP1. Ciência e Natura, v. 39, n. 3, p. 512-519, 2017. Available in: https://doi.org/10.5902/2179460X23281>. doi. $10.5902 / 2179460 \times 23281$

VIEIRA, L. M.; CASTRO, C. F. S.; DIAS, A. L. B.; SILVA, A. R. Fenóis totais, atividade antioxidante e inibição da enzima tirosinase de extratos de Myracrodruon urundeuva Fr. All. (Anacardiaceae). Revista Brasileira de Plantas Medicinais, v. 17, n. 4, p. 521-527, 2015. Available in: http://dx.doi.org/10.1590/1983-084X/13_033>.doi. 10.1590/1983-084X/13_033 